\title{
Epidemiological survey on pandemic influenza $A$ (H1N1) virus infection in Kurdistan province, Islamic Republic of Iran, 2009
}

S. Afrasiabian, ${ }^{1}$ B. Mohsenpour, ${ }^{2}$ K.H. Bagheri, ${ }^{2}$ M. Barari, ${ }^{1}$ E. Ghaderi, ${ }^{3}$ R. Hashemi ${ }^{3}$ and F. Garibi ${ }^{4}$

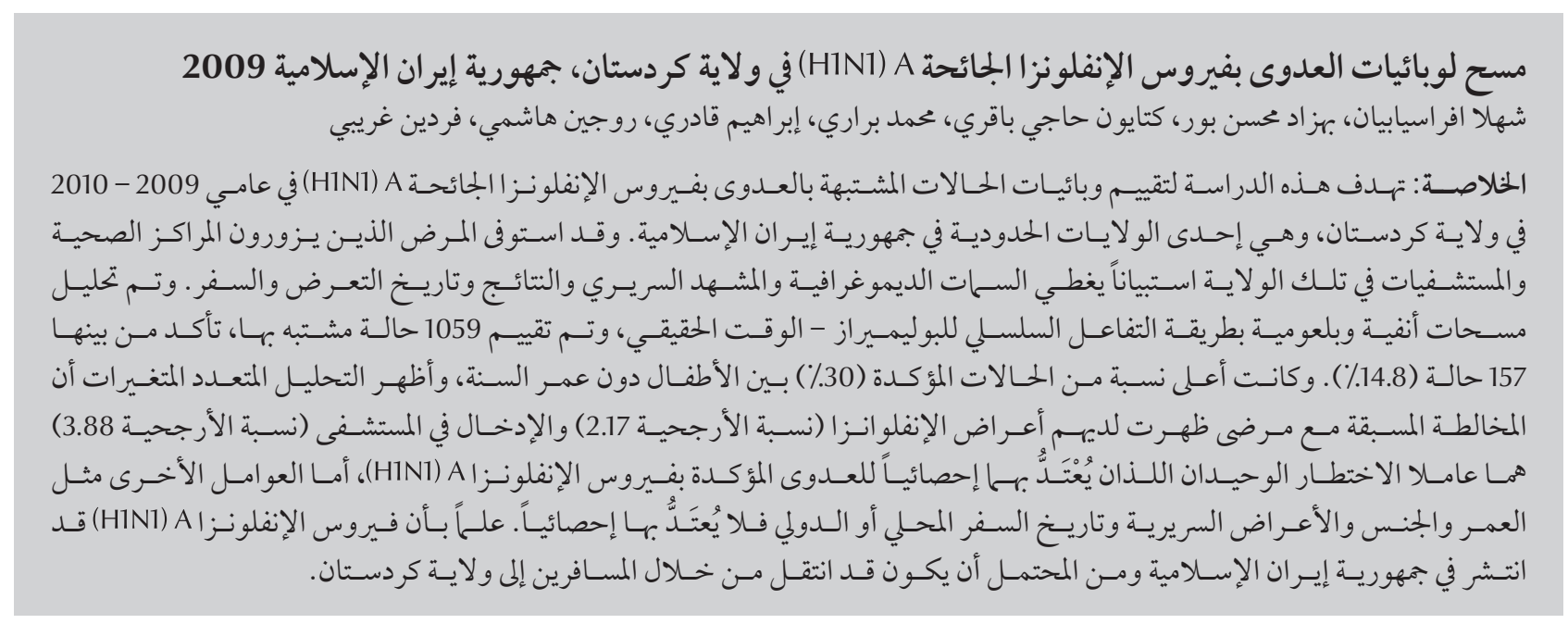

ABSTRACT This study evaluated the epidemiology of suspected cases of pandemic influenza A (H1N1) virus infection in 2009-2010 in Kurdistan province, a frontier province of the Islamic Republic of Iran. A questionnaire covering demographic characteristics, clinical presentation and outcome, and history of exposure and travel was completed by patients attending health centres and hospitals in the province. Nasal and throat swabs were analysed by RT-PCR. A total of 1059 suspected cases were assessed; H1N1 influenza A was confirmed in 157 (14.8\%). The highest proportion of confirmed cases was $30.0 \%$, among children aged $<1$ year. In multivariate analysis, previous contact with symptomatic influenza patients $(\mathrm{OR}=2.17)$ and hospitalization $(\mathrm{OR}=3.88)$ were the only significant risk factors for confirmed H1N1 infection. Age, sex, residency, presenting symptoms and history of national or international travel were not significant. Influenza A (H1N1) virus has spread in Islamic Republic of Iran; probably transmitted by travellers to Kurdistan.

Enquête épidémiologique sur l'infection par le virus de la grippe pandémique $A(H 1 N 1)$ dans la province du Kurdistan (République islamique d'Iran) en 2009

RÉSUMÉ La présente étude visait à évaluer l'épidémiologie des cas suspectés d'infection par le virus de la grippe pandémique $\mathrm{A}(\mathrm{H} 1 \mathrm{N1})$ en 2009-2010 dans la province du Kurdistan, une province frontalière de la République islamique d'Iran. Un questionnaire couvrant les caractéristiques démographiques, la présentation clinique et les résultats ainsi que les antécédents d'exposition et de déplacements a été rempli par les patients consultant dans les centres de santé et les hôpitaux de la province. Des prélèvements de nez et de gorge ont été analysés par PCR en temps réel. Au total, 1059 cas suspects ont été évalués ; le virus de la grippe A(H1N1) a été confirmé dans 157 cas (14,8\%). Le pourcentage le plus élevé de cas confirmés était $30 \%$ chez les enfants de moins d'un an. À l' analyse multivariée, un contact antérieur avec des patients porteurs de symptômes de la grippe (OR = $2,17)$ et une hospitalisation $(O R=3,88)$ étaient les seuls facteurs de risque importants pour une infection à H1N1 confirmée. L'âge, le sexe, le lieu de résidence, les symptômes initiaux ainsi que des antécédents de voyages dans le pays ou à l'étranger n'étaient pas des facteurs significatifs. Le virus de la grippe A(H1N1) s'est propagé en République islamique d'Iran, probablement transmis par des voyageurs qui se rendaient au Kurdistan.. 


\section{Introduction}

The H1N1 influenza A virus is a relatively new virus of swine origin that can spread quickly and has the potential to cause a worldwide pandemic [1-3]. The virus was first detected in humans in Islamic Republic of Iran in 2009. During a short period the disease spread to several other countries [4] including neighbouring countries of the Islamic Republic of Iran [5].

The symptoms of pandemic influenza A (H1N1) are similar to seasonal influenza and include fever, sore throat, body pain, cough, rhinitis, headache, shivering and gastrointestinal complications. Although some symptoms are specific to the severity and regions of the infection [6], most patients show slight or self-limiting disease $[4,7,8]$. As most patients have mild symptoms, it is likely that just a small proportion of infected patients are registered $[8]$ and therefore incidence estimates are not exact. About half of H1N1-infected patients have previous history of contact with a symptomatic influenza patient and one-third of them have a history of foreign travel [7]. In most cases of H1N1 infection, patients are younger than 30 years $[7,9]$. Unfortunately, routine seasonal vaccination is not effective against pandemic influenza A (H1N1) virus [10].

Two peaks of disease incidence occurred in the Islamic Republic of Iran during the period 1 June to 11 November 2009. Travelling abroad and the start of the educational year were the main explanations for the first and second peaks respectively [11]. Kurdistan province with a population of about 1.4 million, is located in western part of the Islamic Republic of Iran. This is a frontier province with $230 \mathrm{~km}$ common border with its neighbouring country of Iraq. There are some cross-border shopping markets in this province attracting many Iranian travellers. Therefore, monitoring the incidence of diseases is important in Kurdistan province. Furthermore, there is no efficient health surveillance system in the Kurdistan region of Iraq. Therefore, evaluation of the characteristics of confirmed cases of H1N1 is of prime importance to adopt effective prevention and controlling strategies regarding $\mathrm{H} 1 \mathrm{~N} 1$. The present study aimed to evaluate the prevalence and time trend of pandemic influenza A (H1N1) virus in Kurdistan province of Islamic Republic of Iran to define the main factors influencing the spread of this pandemic virus. The confirmed and suspected cases of $\mathrm{H} 1 \mathrm{~N} 1$ virus infection and their characteristics were evaluated in this frontier province.

\section{Methods}

This was a follow-up survey conducted during April 2009 to March 2010 in Kurdistan province.

\section{Sample}

The research population consisted of all suspected cases of pandemic influenza $\mathrm{A}(\mathrm{H} 1 \mathrm{~N} 1)$ virus infection who had attended health-care centres and hospitals in Kurdistan province over the study period. A suspected case was defined as follows: fever above $38^{\circ} \mathrm{C}$, or having at least 2 respiratory symptoms including rhinorrhoea, sore throat or cough in addition to at least 1 of the following: (1) history of travel to an H1N1 epidemic area during the last 7 days; (2) history of contact with an H1N1 infected patient; (3) severe pulmonary disease or any unknown pulmonary disease causing death.

\section{Data collection}

According to the Iranian national $\mathrm{H} 1 \mathrm{~N} 1$ influenza surveillance, the suspected patients were reported to the national centre for disease control. Trained staff took nasal and throat swabs from all suspected patients and sent samples to the national reference laboratory at Tehran University of Medical Sciences, Islamic Republic of Iran. The samples were examined by real-time polymerase chain reaction (RT-PCR) as developed by the United States Centers for Disease Control and Prevention for the detection of pandemic $\mathrm{H} 1 \mathrm{~N} 1$ virus, as recommended by World Health Organization (WHO) [12]. A researcherdesigned questionnaire containing items related to demographic data (age, sex and residency), clinical symptoms, contact history and national and international travel history was completed by all subjects. Outcomes, including hospitalization and death, were noted for presenting patients.

\section{Data analysis}

The data were entered into SPSS software, version 11.5. The percentages, means, standard deviation (SD) and frequency distributions of variables were calculated using descriptive statistics. Univariate analyses were performed using the chi-squared and $t$-test to assess the difference between the confirmed and unconfirmed cases of H1N1. In the next step, odds ratio (OR) and its confidence intervals (CI) were calculated. Variables with $P$-values $<0.25$ in univariate analysis were entered into a multivariate analysis using logistic regression to find predictable characteristics related to $\mathrm{H} 1 \mathrm{~N}$-infected patients after adjustment for other variables.

\section{Results}

A total of 1059 people, registered as suspected cases of pandemic influenza A (H1N1) virus in Kurdistan province, were included in the study. Of the total group 558 people were female (52.7\%) and 911 were urban residents (86.0\%). Most cases of suspected H1N1 infection were detected in October (Figure 1).

The disease was confirmed in 157 cases $(14.8 \%)$. The mean age of the confirmed and unconfirmed H1N1infected patients was 21.8 (SD 15.2) years and 20.7 (SD 19.3) years respectively $(P=0.44)$. The ages of confirmed 


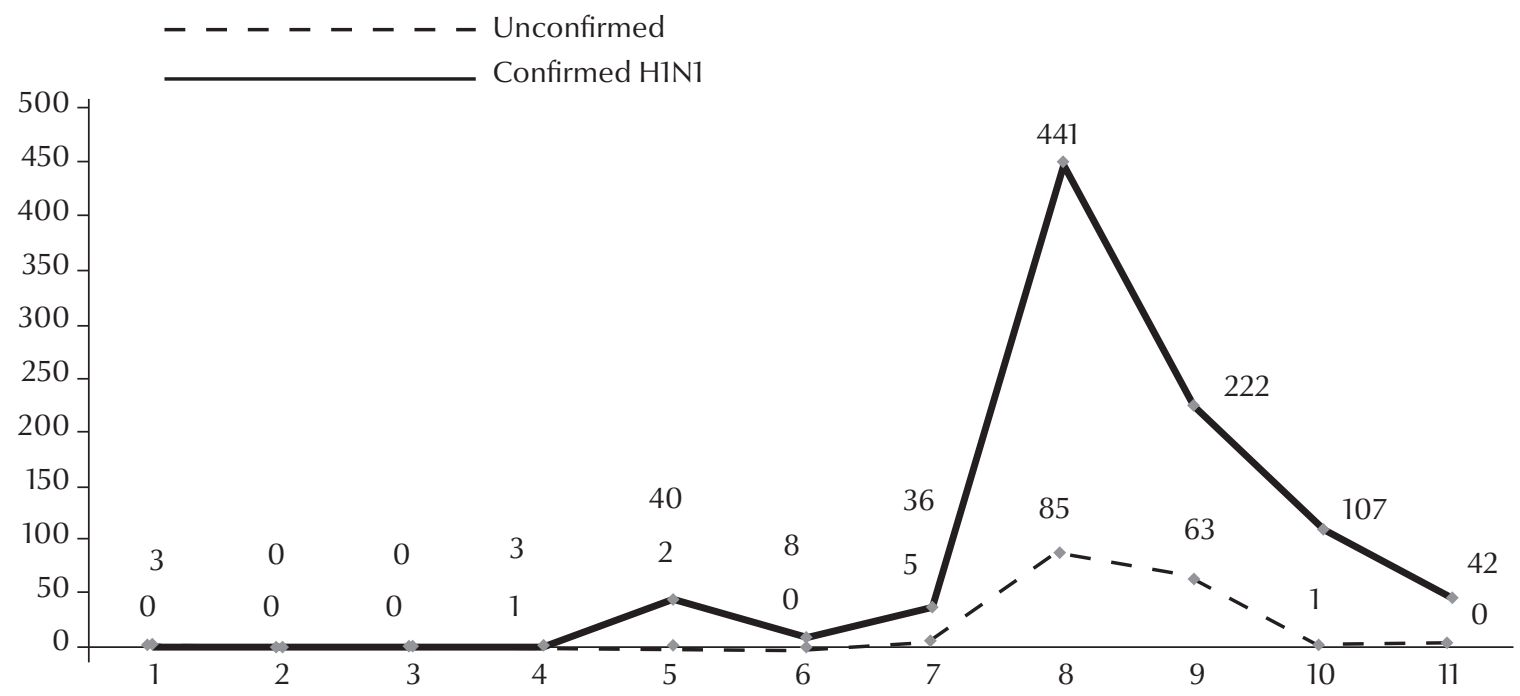

Figure 1 Frequency of confirmed and unconfirmed cases of pandemic influenza A (H1N1) based on month of occurrence (bold numbers $=$ H1N1 patients)

H1N1-infected patients ranged from < 1 to 80 years and of the unconfirmed group from < 1 year to 86 years. The highest percentage of H1N1-confirmed patients $(30.0 \%)$ was observed among children aged $<1$ year (Figure 2).

The mean time interval between the onset of symptoms and first health care attendance of the confirmed cases was 2.7 (SD 2.6) days and the median was 2 (ranged 0 to 15 ) days. A total of 158 people (14.9\%) reported previous contact with an influenza symptomatic patient: $29.3 \%$ of the confirmed cases and $12.4 \%$ of the unconfined cases $(P<0.001)$. Three H1N1-infected patients had a history of travel abroad: 1 of them had visited Saudi Arabia and the other 2 did not mention the place. In the unconfirmed group, 11 persons had visited Saudi Arabia, 4 Dubai and 1 Iraq and 3 had visited other countries. Overall, 788 suspected cases (74.4\%) were hospitalized: $91.7 \%$ of the confirmed cases and $71.4 \%$ of the unconfined cases $(P<0.001)$. No deaths were reported among the
Unconfirmed

Confirmed H1N1

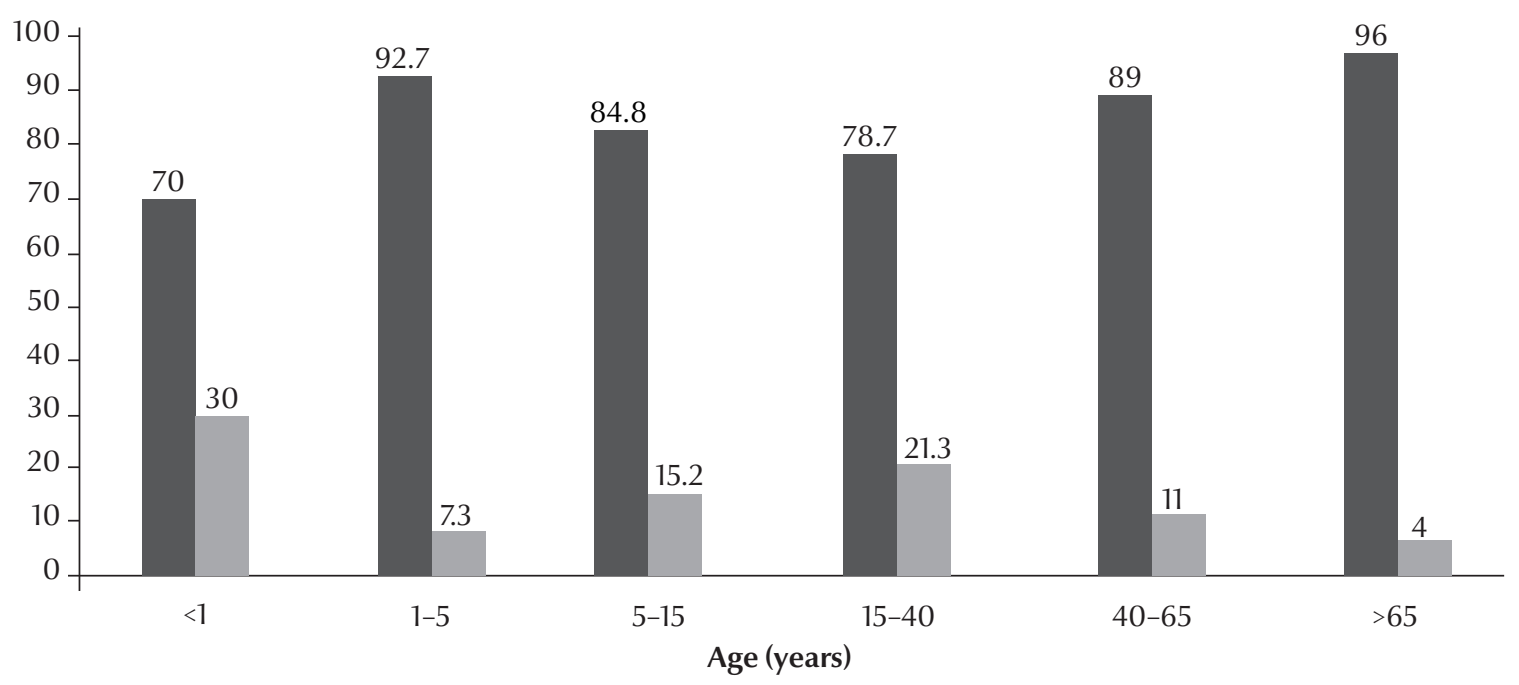

Figure 2 Comparison of the percentage of confirmed and unconfirmed cases of pandemic influenza A (H1N1) by age group 


\begin{tabular}{|c|c|c|c|c|c|c|}
\hline \multirow[t]{2}{*}{ Variable } & \multicolumn{2}{|c|}{$\begin{array}{l}\text { Confirmed H1N1 cases } \\
\qquad(n=157)\end{array}$} & \multicolumn{2}{|c|}{$\begin{array}{l}\text { Unconfirmed cases } \\
\qquad(n=902)\end{array}$} & \multirow[t]{2}{*}{ Unadjusted OR (95\% Cl) } & \multirow[t]{2}{*}{$P$-value } \\
\hline & No. & $\%$ & No. & $\%$ & & \\
\hline \multicolumn{7}{|l|}{ Sex } \\
\hline Male & 65 & 41.4 & 436 & 48.3 & $0.76(0.54-1.07)$ & \multirow{2}{*}{0.108} \\
\hline Female & 92 & 58.6 & 466 & 51.7 & & \\
\hline \multicolumn{7}{|l|}{ Residency } \\
\hline Urban & 141 & 89.8 & 770 & 85.4 & $1.51(0.87-2.62)$ & \multirow{2}{*}{0.138} \\
\hline Rural & 16 & 10.2 & 132 & 14.6 & & \\
\hline \multicolumn{7}{|c|}{ Domestic travel history } \\
\hline Yes & 1 & 0.6 & 24 & 2.7 & $0.24(0.03-1.75)$ & \multirow{2}{*}{0.123} \\
\hline No & 156 & 99.4 & 878 & 97.3 & & \\
\hline \multicolumn{7}{|c|}{ International travel history } \\
\hline Yes & 3 & 1.9 & 27 & 3.0 & $0.63(0.19-2.11)$ & \multirow{2}{*}{0.451} \\
\hline No & 154 & 98.1 & 875 & 97.0 & & \\
\hline \multicolumn{7}{|c|}{ Contact history } \\
\hline Yes & 46 & 29.3 & 112 & 12.4 & 2. $92(1.97-4.35)$ & \multirow{2}{*}{$<0.001$} \\
\hline No & 111 & 70.7 & 790 & 87.6 & & \\
\hline \multicolumn{7}{|c|}{ Hospitalization } \\
\hline Yes & 144 & 91.7 & 644 & 71.4 & $4.44(2.47-7.97)$ & \multirow{2}{*}{$<0.001$} \\
\hline No & 13 & 8.3 & 258 & 28.6 & & \\
\hline \multicolumn{7}{|l|}{ Fever } \\
\hline Yes & 151 & 96.2 & 819 & 90.8 & 2.55 (1.09-5.95) & \multirow{2}{*}{0.025} \\
\hline No & 6 & 3.8 & 83 & 9.2 & & \\
\hline \multicolumn{7}{|l|}{ Body pain } \\
\hline Yes & 118 & 75.2 & 588 & 65.2 & $1.62(1.10-2.38)$ & \multirow{2}{*}{0.014} \\
\hline No & 39 & 24.8 & 314 & 34.8 & & \\
\hline \multicolumn{7}{|l|}{ Cough } \\
\hline Yes & 140 & 89.2 & 754 & 83.6 & $1.62(0.95-2.76)$ & \multirow{2}{*}{0.075} \\
\hline No & 17 & 10.8 & 148 & 16.4 & & \\
\hline
\end{tabular}

$O R=$ odds ratio; $C l=$ confidence interval.

unconfirmed and confirmed H1N1infected cases (Table 1).

In univariate analysis, there was no significant difference between confirmed and unconfirmed H1N1 patients $(P>0.05)$ with respect to sex, urban/rural residency, Domestic and international travel history but we found significant differences between confirmed and unconfirmed H1N1 patients according to contact history, hospitalization, fever and body pain $(P$ $<0.05$. However, in multivariate analysis, previous contact with symptomatic influenza patients $(\mathrm{OR}=2.17$; $95 \%$ CI: 1.41-3.32) and getting hospitalized
$(\mathrm{OR}=3.88$; 95\% CI: 2.12-7.11) were the only significantly risk factors for confirmed H1N1-infection $(P<0.001)$ (Table 2).

\section{Discussion}

Our findings showed that both the frequency of previous contact with symptomatic influenza patients and the rate of hospitalization were higher in patients confirmed with pandemic influenza $\mathrm{A}(\mathrm{H} 1 \mathrm{~N} 1)$ virus infection compared with those not confirmed. As a history of international travel was not a significant risk factor for confirmed disease, travelling to neighbouring Iraq presumably did not have an impact on the influenza epidemic in Kurdistan province of the Islamic Republic of Iran. The peak incidence of the disease occurred in September and October and, considering the age group of samples, these peaks can be attributed to transmission of the disease in universities and schools. Only 1 of the confirmed cases had a history of a domestic trip. Therefore, it seems likely that the disease was transmitted by travellers who came to Kurdistan. The findings of Gooya et al.'s study in the Islamic Republic of 


\begin{tabular}{lccc}
\hline $\begin{array}{l}\text { Table } 2 \text { Relationship between confirmed cases of pandemic influenza A (H1N1) virus infection and the study variables: } \\
\text { multivariate logistic regression analysis }\end{array}$ & \multicolumn{4}{l}{ Adjusted OR (95\% CI) } & $\boldsymbol{P}$-value \\
\hline Variable & -0.002 & $0.99(0.99-1.01)$ & 0.657 \\
Age & -0.216 & $0.81(0.56-1.16)$ & 0.240 \\
Sex (male/female) & 0.248 & $1.28(0.73-2.26)$ & 0.393 \\
Residency (rural/urban) & -0.605 & $0.55(0.07-4.31)$ & 0.566 \\
Domestic travel history (yes/no) & 0.773 & $2.17(1.41-3.32)$ & $<0.001$ \\
Contact history (yes/no) & 0.757 & $2.13(0.89-5.09)$ & 0.089 \\
Fever (yes/no) & 0.271 & $1.31(0.85-2.03)$ & 0.224 \\
Body pain (yes/no) & 0.080 & $1.08(0.62-1.90)$ & 0.781 \\
Cough (yes/no) & 1.357 & $3.88(2.12-7.11)$ & $<0.001$ \\
Hospitalization (yes/no) & &
\end{tabular}

$O R=$ odds ratio; $C l=$ confidence interval.

Iran showed a high incidence of pandemic influenza $\mathrm{A}(\mathrm{H} 1 \mathrm{~N} 1)$ virus in neighbouring provinces to Kurdistan [11]. In their study, travelling abroad had a significant impact on the occurrence of the first peak of pandemic $\mathrm{H} 1 \mathrm{~N} 1$ virus infection in the Islamic Republic of Iran, and reopening the universities and schools at the middle of September caused the second peak. Letting students stay at home and closing schools and classes in regions with high numbers of suspected cases of influenza were effective strategies in controlling the disease. These strategies were recommended by the Iranian centre for disease control. This 2-peak pandemic trend was observed in the other provinces as well [11].

The mean age of the confirmed cases in our study was 21.8 years and this was similar to other studies $[3,5,6,13-16]$. In our study there was just 1 person aged $>65$ years. The lower level of infection and susceptibility to $\mathrm{H} 1 \mathrm{~N} 1$ virus in this age group compared with younger age groups can be explained by pre-existing immunity, fewer contacts with other people and lower chances of being in crowded places. On the other hand, in Islamic countries elderly people are more likely to make religious pilgrimages, for example to Saudi Arabia, and this puts them at risk of contagious diseases. Therefore, this age group needs constant monitoring.
Cough and fever were the most common symptoms of the disease. However, the frequency of symptoms varies widely in different countries [3,5,6,13-19]. Different studies showed that most cases of infected H1N1 were mild, and severe cases of the disease were rare $[4,5,8,20]$. It is probable that in Kurdistan some patients with mild symptoms did not attend medical clinics and/or health staff did not consider some patients as suspected cases of $\mathrm{H} 1 \mathrm{~N} 1$ virus influenza and only assessed those with more severe symptoms. Therefore, it is necessary to perform studies assessing the level of awareness, knowledge and practice about $\mathrm{H} 1 \mathrm{~N} 1$ virus infection among health-care workers.

In our study the percentage of hospitalized patients was higher than other similar studies $[3,7,14,21]$. Unnecessary hospitalization may squander financial and human resources in health systems, and physicians therefore need proper training about H1N1 influenza A detection in order to avoid unnecessary referrals. As the rate of hospitalization in the confirmed H1N1 group was $91.7 \%$ compared with $71.4 \%$ for the unconfirmed group, and as no deaths occurred in the hospitalized patients, it can be concluded that hospital filing and caring systems in our hospitals are effective and satisfactory. The reported death rate from pandemic influenza A ( $\mathrm{H} 1 \mathrm{~N} 1)$ virus is low in many countries, ranging from $0 \%$ to $2.2 \%$ of cases $[4,5,9-11,14,22]$. In the present study none of the patients died. We used the WHO guidelines for treatment of patients and this may be responsible for the low virulence level of the virus.

About $30 \%$ of the province's population live in rural areas, and an active surveillance system is implemented in these rural areas. Therefore, we expected more patients to be have been screened in these areas. In our present study, most of the H1N1infected patients were urban residents (89.8\%), which can be attributed to the more frequent contacts and being in more crowded places. Furthermore, few travellers went to rural regions. Therefore, more training should be provided for urban schools and public places as well as for those villagers travelling to the cities.

There was no sex difference in the incidence of confirmed pandemic influenza A (H1N1) in our study, although other studies have reported sex differences $[13,15,18,20]$ and this has been explained by the higher level of social involvement of men than women [14].

We did not study the incubation period of the virus, but only noted that the mean time interval between onset of symptoms and first health care 
attendance of all participants was 2.7 (SD 2.6) days. In other studies the mean delay ranged from $1.8-3$ days $[3,5,13,14,16,18,20]$.

In conclusion, it seems that influenza A (H1N1) virus has spread in the Islamic Republic of Iran and was probably transmitted by travellers who came to Kurdistan. Older people are less likely to become infected. We also conclude that caring and reporting systems related to influenza A surveillance in the province hospitals are well implemented.

\section{Acknowledgements}

The authors thank all staff of the Iranian centre for disease control and Kurdistan University of Medical Sciences and staff of the influenza reference laboratory.

Competing interests: None declared

\section{References}

1. Rossman JS, Lamb RA. Swine-origin influenza virus and the 2009 pandemic. American Journal of Respiratory and Critical Care Medicine, 2010, 181:295-296.

2. Influenza-like illness in the United States andMexico. Disease outbreak news. 24 April 2009. World Health Organization [online factsheet] (http://www.who.int/csr/don/2009_04_24/en/, accessed 30 July 2013).

3. Dawood FS et al. Emergence of a novel swine-origin influenza $\mathrm{A}(\mathrm{H} 1 \mathrm{~N} 1)$ virus in humans. New England Journal of Medicine, 2009, 360:2605-2615.

4. Health Protection Agency. Epidemiology of new influenza $\mathrm{A}(\mathrm{H} 1 \mathrm{~N} 1)$ in the United Kingdom, April-May 2009. Eurosurveillance, 2009, 14:6-8.

5. Ciblak MA et al. Cases of influenza $A(\mathrm{H} 1 \mathrm{~N} 1) \mathrm{v}$ reported in Turkey, May-July 2009. Eurosurveillance, 2009, 14:19304.

6. Boni MF et al. Modelling the progression of pandemic influenza A (H1N1) in Vietnam and the opportunities for reassortment with other influenza viruses. BMC Medicine, 2009, 7:43-55

7. Cao B et al. Clinical features of the initial cases of 2009 pandemic influenza A ( $\mathrm{H} 1 \mathrm{N1})$ virus infection in China. New England Journal of Medicine, 2009, 361:2507-2517.

8. AIMazroa MA, Memish ZA, AIWadey AM. Pandemic influenza A (H1N1) in Saudi Arabia: description of the first one hundred cases. Annals of Saudi Medicine, 2010, 30:11-14

9. Cutter JL et al. Outbreak of pandemic influenza A (H1N1-2009) in Singapore, May to September 2009. Annals of the Academy of Medicine, Singapore, 2010, 39:273-282.

10. Cutler J et al. Investigation of the first cases of human-tohuman infection with the new swine-origin influenza A (H1N1) virus in Canada. Canadian Medical Association Journal, 2009, 181:159-163.

11. Gooya MM et al. Influenza A (H1N1) pandemic in Iran: report of first confirmed cases from June to November 2009. Archives of Iranian Medicine, 2010, 13:91-98.
12. CDC protocol of realtime RT-PCR for swine influenza $A$ (H1N1). April 28 2009. Revision 1 (30 April 2009). Geneva, World Health Organization, 2009 (http://www.who.int/csr/resources/publications/swineflu/CDCrealtimeRTPCRprotocol_20090428.pdf, accessed 30 July 2013).

13. Crum-Cianflone NF et al. Clinical and epidemiologic characteristics of an outbreak of novel H1N1 (swine origin) influenza A virus among United States military beneficiaries. Clinical Infectious Diseases, 2009, 49:1801-1810.

14. Gianella A et al. Epidemiological analysis of the influenza $\mathrm{A}(\mathrm{H} 1 \mathrm{N1}) \mathrm{V}$ outbreak in Bolivia, May-August 2009. Eurosurveillance, 2009, 14:19323.

15. Gomez-Gomez A et al. Severe pneumonia associated with pandemic (H1N1) 2009 outbreak, San Luis Potosi, Mexico. Emerging Infectious Diseases, 2010, 16:27-34.

16. Leonardi GP et al. Public hospital-based laboratory experience during an outbreak of pandemic influenza $A(H 1 N 1)$ virus infections. Journal of Clinical Microbiology, 2010, 48:11891194.

17. Saxena SK et al. Swine flu: influenza A/H1N1 2009: the unseen and unsaid. Future Microbiology, 2009, 4:945-947.

18. Lessler J et al. Outbreak of 2009 pandemic influenza A (H1N1) at a New York city school. New England Journal of Medicine, 2009, 361:2628-2636.

19. Ou Q et al. Clinical analysis of 150 cases with the novel influenza A ( $\mathrm{H} 1 \mathrm{~N} 1)$ virus infection in Shanghai, China. Bioscience Trends, 2009, 3:127-130.

20. Shen Y, Lu H. Pandemic (H1N1) 2009, Shanghai, China. Emerging Infectious Diseases, 2010, 16:1011-1013.

21. Reed C et al. Estimates of the prevalence of pandemic (H1N1) 2009, United States, April-July 2009. Emerging Infectious Diseases, 2009, 15:2004-2007.

22. Deo MG. Host factors in swine flu pandemic in India. Indian Journal ofMedical Research, 2009, 130:772-773. 